\section{Executive Director Reports, continued}

Golden Year Club members and Continuing Forestry Education certificate recipients will be honoured.

Sunday night will kick off the conference Global Approaches to Sustainable Forest Management with an ice-breaker and flavours of the west coast. On Monday, the conference will begin. The program emphasizes Certification and Criteria and Indicators - a topic that is forever evolving. This international conference, (co-hosted by the CIF/IFC and the McGregor Model Forest Network) emphasizes not only the Canadian perspective on certification and criteria and indicators, but also the temperate and tropical forests perspective. Speakers from around the world will discuss their processes and steps towards sustainable forest management practices. Workshops will be incorporated into the conference giving participants an opportunity to discuss issues that we face on the ground.

For more than 85 years CIF/IFC meetings have been the meeting place for members and like-minded. We realize that many forestry conferences are held throughout the year. We hope that this conference will be the one you will attend. We look forward to seeing you there.
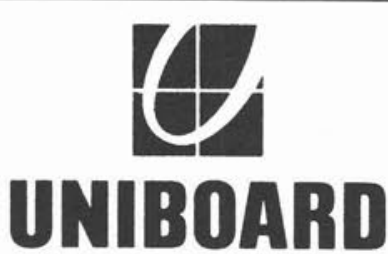

UNIBOARD CANADA INC@

\section{A CIF/IFC Corporate Sustaining Member}

\section{CIF/IFC Gold Medal Winners}

\section{Lynda Catherine (Cathy) \\ Rutherford, Sault College}

Cathy has been an outstanding student, volunteer and academic tutor during her time at Sault College where she completed her Forest Technician Diploma in December 1996. Awarded the Hodgson trophy and Ramada Inn Scholarship for academics and athletics, Cathy was assistant captain of the college intramural Timbersports team and a gold medalist in the pole climb, the horizontal chop and waterboiling events.

Cathy is an avid hiker, skiier, and camper who enjoys outdoor activity year round. She has shown great leadership skills while attending Sault College, has worked as a volunteer peer tutor as well as gaining certification in chainsaw safety, first aid and CPR. Cathy has returned to her native Nova Scotia where she is employed by the Pictou Forest Owners Association.

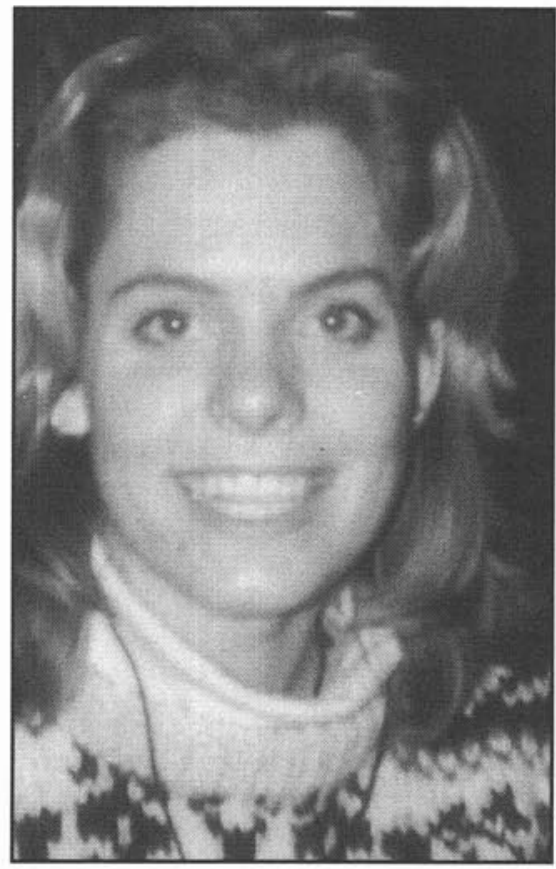

\section{Brad Tanner, British Columbia Institute of Technology}

Brad is a second-year Forestry student who is currently enrolled in the fourth of four terms required for the completion of a diploma in Forestry. Brad has had the highest GPA averaged over the last two terms of anyone currently in a second year Forestry program. Last term, Brad received marks in the nineties in both the Technical Communications course and the Forest Engineering course. Brad's achievements are even more exceptional considering he became a father for the first time midway through last term!

Brad gets along exceptionally well with fellow students often working late helping other students in study groups.

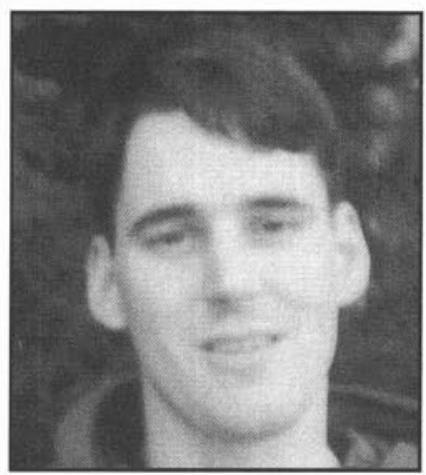

\title{
Alberta Forest Technologists Association
}

The AFTA is group of like-minded technologists dedicated to the responsible practice of forestry within the province of Alberta. There are exciting days ahead for the Alberta Forest Technologists Association. Our Executive Committee is currently working on the development and implementation of a business plan, the electronic posting of our members handbook, the tracking of our members educational and professional achievements and the joint pursuit of the Licence to Practise Initiative with the Alberta
Registered Professional Foresters Association.

We are an organization with 140 paid members from industry and governmental agencies. We are on the World Wide Web at http://www.nofc. forestry.ca/afta. Members of our Executive Committee can be reached by e-mail from this page. At our annual general meeting, held February 22, 1997, the association dealt with a number of housekeeping issues. Tracey Cove was elected to continue in the role of President. Jules
LeBeouf was elected to the position of Vice-President. Other members of the executive are; Len Stroebel - Treasurer, Bill Tinge - Secretary, Joerg Goetsch Education Committee, Roger Tetrault - Conduct and Ethics Committee, Dave Lind - Membership Committee, Bill Black - Communications Committee and Daryl Sande - CIF Representative.

Bill Black Communications Chair AFTA 